味では羡ましくも思えた。今，日本では大学におい ても国際化が叫ばれているが，上述のようにアメリ カではだまっていても海外から留学生が集まってく る。これには, いくつかの理由があるが, 言語の問 題も関係している。わが国では，とにかく日本語の できない留学生はお手上げである。

大学院の学生と教員の関係は, 教員おのおのの考 え方にも左右されるが, Give and Take の感じをも った。また, 学生寮, 運動施設, 図書館, 情報関連 施設などは充実しており, 学生は健康に留意しつつ, 各施設を十分に利用しながら静かな環境の中で研究 に没頭することができる。時々，警報器が詰動作し，
長時間の騒々しいベルの音の後, 消防車の訪問に出 会うこともあったが, 私にとっては, 変化の少ない 生活のなかで息抜きをするときでもあった。

最後に，本稿を執筆するにあたりご協力をいただ きましたケンタッキー大学機械工学科助教授, 斉藤 孝三先生にこの場をかりてお礼申し上げます。

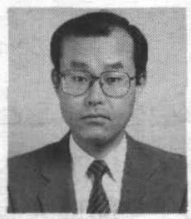

三木 一郎: 昭和56年 3 月, 明治大学 大学院工学研究科電気工学専攻博士課程 修了. 工学博士

現在, 明治大学工学部助教授

\title{
II－8 アメリカ,テキサス大学での工学教育
}

Education of Engineering at University of

Texas in U.S.A.

\section{梅 原 秀 哲 \\ Hidetaka UMEHARA}

私は, 1978 年 8 月から 82 年3月まで, アメリカ のテキサス大学工学部土木工学科博士課程に在籍し ておりました。そしてその後, 名古屋工業大学に赴 任し，学生を教育する立場になってあらためて，日 本とアメリカの工学教育に大きな違いを感じました。 したがって,ここでは外国の大学としてアメリカを 対象として, 工学教育を比較してみたいと思います。 テキサス大学は州立大学であり,一般にアメリカ では税金を納めている人の子弟は, その居住してい る州の州立大学に入学できる権利があるという意識 が強いため, 高校で良い成績を修めている学生はほ とんど推薦で入学できるようです。したがって, 新 入生の学力のレベルは, 日本のように受験地獄を勝 ち抜いた者が入学できるシステムでないため, 日本 に比べ劣っていると言えます。しかし,これが大学 4 年間でほとんど同じレベルか, または逆転してし まうようです。

テキサス大学では秋, 春の 2 学期制 (夏学期もあ リますが開講される科目数が半分以下です) で, 学 生は 1 学期に最低 4 科目を履習しなけれはなりませ
ん。 1 科目週 3 時間 3 単位 (月・水・金各 1 時また は火・木各 1.5 時間) の授業ですから， 1 週間で 12 時間の講義を受けるだけで， あとは何をしようと自 由なわけです。しかし, 学生は毎週宿題で追いまく られ，2回か 3 回の中間試験と期末試験で勉強に䋘 リつけられます。成績は宿題と試験の結果で機械的 に処理され, 成績が悪いと留年ではなく, レベルの 低い大学へ転校させられたり, 奨学金がもらえなく なるなど非常に厳しい措置がとられます。したがっ て, 卒業時の学生数が入学時の半分以下になる場合 がほとんどです。一方, 日本の大学では，1科目週 1 時間半の授業で 1 学期に 10 科目以上受講する必要 があります。毎週宿題が出る科目は, 演習の授業ぐ らいでほとんどなく, また中間試験のある科目も少 なく、ほとんどが期末試験だけで成績が決まります。 成績が悪いと留年になるだけで，転校などの処分は ほとんどありません。さらに, アメリカではほとん どの大学で, 学生が教官を評価するシステムがあり ます。学期の最後に各学生にその授業を評価する用 紙が渡され, その講義がわかりやすかったか, 役に 
立ったか，興味を持たせるような教え方をしていた か等が問われます。この評価は，その教官の昇給や 昇進に影響するため, 教官も授業に対して真剣に取 り組まざるをえないようです。

さて授業ですが，テキサス大学では 1 学期に受講 すべき科目数が少ないため, 学生は日本の大学のよ うに一般教養をほとんど受講する必要がありません。 しかし, 工学系の学生は工業数学と工業物理を受講 しなければ, 専門科目が受けられません。土木工学 科では, 学生は日本の大学と同様に, 学部の間は土 木工学全体の授業を取らされ，その内容は日本の大 学と同程度です。しかし，4 年生になると, 土木構 造物の実際の設計など卒業すればすぐに第 1 線で活 躍できるような授業内容になります。これは余談で すが, アメリカでは大学の教官がコンサルタントを 副業としている場合が多く, 時には自分の請け負っ た設計を宿題として学生に出し，その中で優秀な設 計を選んで採用する場合があります。学生にとって は設計の練習であり, 非常に役立つだけでなく, 教 官にとっては非常に楽な金儲けなのです。以上が学 部の授業についてですが, 日本の大学に比べ卒業後 すぐに社会で役に立つような実践的な教育が行われ, また学生も宿題に追われ, まじめに勉強せざるを得 ないようなシステムになっているため，卒業時には アメリカの学生の学カレベルは, 日本の学生と同レ ベルかそれ以上になるようです。

アメリカでは学部の学生は卒業論文を書く必要が なく, 論文を書く必要があるのは修士課程の学生か らです。彼らは授業を受けるかたわら, 論文のため
の研究を行っています。奨学制度としてTeaching Ass is tant ship と Reseach Assistantship があり ほとんどの学生がこのどちらかの奨学金をもらって います。前者 (TA) は学部の授業の宿題の採点をし 後者 (RA) は教官の代りに実験研究を行う義務があ ります。教官は, いくつかのプロジェクトを外部 (国や州の公共機関や民間企業) から請け負い，各 プロジェクトに含まれているRAの費用に応じて学 生にRAを与え, 研究させるわけです。学生にとっ ては, 自分の論文のための研究を行いながら奨学金 がもらえるため, 一石二鳥です。一方, 教官にとっ ては, プロジェクトがなければ研究できなくなるた め,プロジェクトの数が教官の評価につながります。 授業において, 宿題を毎週出して中間試験を 2 回 ほど行うことは, TAとして雇った学生の助けがあ って初めてできるもので, 教官 1 人では宿題や試験 の採点の量が多く，かなリの重労働になリます。ま た研究においても, 日本ではスポンサーのつくよう なプロジェクトは数が少なく, 学生に奨学金を与え られるような金額ではありません。しかし，日本に 比べて大学 4 年間での学生の学力の向上が著しく, その教育の成果が明確にあらわれていることは, 注 目に値すると思われます。

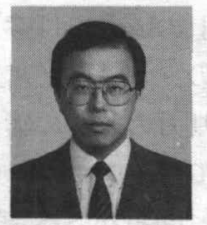

梅原 秀哲 : 昭和 51 年, 東京大学工学 部土木工学科卒. 昭和 57 年, テキサス大 学大学院土木工学科博士課程修了. Ph.D. 現在, 名古屋工業大学工学部助教授 (社 会開発工学科)

\section{II -9 日本のエ業教育とアメリカのエ業教育}

\section{堂山昌 男 Masao DOHYAMA}

アメリカの工学部における学生生活と日本におけ る学生生活を比較するようにとのご依頼があった。 私が初めてアメリカに渡ったのは昭和 29 年の正月で
あった。今とは大分事情が異なる。結局 1 年の予定 で行ったのが14年程アメリカに居座り, 永住権も取 リ，一時はアメリカの土となることを覚悟したが, 